7. Reprod. Fert. (1969) 19, 223-229

\title{
TIMING OF LH RELEASE AND OVULATION IN THE CYCLIC MOUSE
}

\author{
AUDREY S. BINGEL* AND NEENA B. SCHWARTZ \\ Department of Physiology, University of Illinois College of Medicine, \\ Chicago, Illinois, U.S.A.
}

(Received 1st April 1968, revised 16th September 1968)

\begin{abstract}
Summary. The time at which ovulation occurred on the morning of oestrus in unmated cyclic mice was investigated. Ovulation was found to occur during the late part of the dark period and early part of the light period (lights on from 05.00 to 19.00 hours). Barbital was administered at different times before the expected time of ovulation in an effort to determine the time of the ovulatory release of $\mathbf{~ L H}$. Barbital injection at 17.00 hours, but not at 21.00 hours, on the day of pro-oestrus prevented the appearance of ovarian evidence of $\mathbf{L H}$ release as indicated by the absence both of ovulation and of stimulated follicles.
\end{abstract}

\section{INTRODUCTION}

In the rat exhibiting either 4- or 5-day oestrous cycles, the surge of Lry responsible for ovulation is released from the anterior pituitary after 14.00 hours on the day of pro-oestrus (lights on from 05.00 to 19.00 hours) (Mills \& Schwartz, 1961; Schwartz \& Bartosik, 1962; Schwartz \& Caldarelli, 1965). Untreated 4-day cyclic rats housed under conditions of $14 \mathrm{hr}$ light and $10 \mathrm{hr}$ darkness (L14:D10; 24.00 hours = midpoint of the dark period) ovulate at about 02.00 hours on the morning of oestrus (Everett, 1961). Pentobarbital injection at 14.00 hours on the day of pro-oestrus, delays ovulation a full $24 \mathrm{hr}$ (Everett, 1961), but pentobarbital administration at 16.00 hours is ineffective, indicating that sufficient LH had already been released by 16.00 hours. Rats exhibiting 5-day cycles have a prolonged critical period for LH release; pentobarbital at 14.00 hours does not block ovulation, but barbital (a long-acting barbiturate) administered at 13.00 hours does (Hoffmann \& Schwartz, 1965). The time of ovulation in rats with 5-day cycles, however, has not been investigated.

Ovulation time has been studied in the mouse as well, but predominantly in the mated animal (Snell, Fekete, Hummell \& Law, 1940; Braden \& Austin, 1954; Braden, 1957). Although different strains and different lighting conditions were used, there was a tendency for the majority of animals to ovulate between 24.00 and 08.00 hours (see Text-fig. 1). Assuming a 12-hr latent period for LH

* Present address : Department of Pharmacognosy and Pharmacology, University of Illinois College of Pharmacy, Chicago, Illinois, U.S.A. 
in the mouse (Runner \& Palm, 1953), as is found in the rat (Rowlands \& Williams, 1943), these observations appear to indicate that in the mouse, the release of $\mathrm{LH}$ responsible for ovulation occurs during the afternoon and early evening of pro-oestrus.

The high degree of variability in the time of ovulation in the mouse (Textfig. 1) as compared with that in the rat could represent a real species difference and/or be an effect of the presence of a male or of the copulatory stimulus itself. Males were not employed in the studies using the rat (Everett, 1961). The two-fold purpose of the present study was to ascertain the time of ovulation in the unmated cyclic mouse in the same lighting conditions under which the unmated cyclic rat has been studied, and to investigate whether a 'critical period' for LH release exists in the mouse.

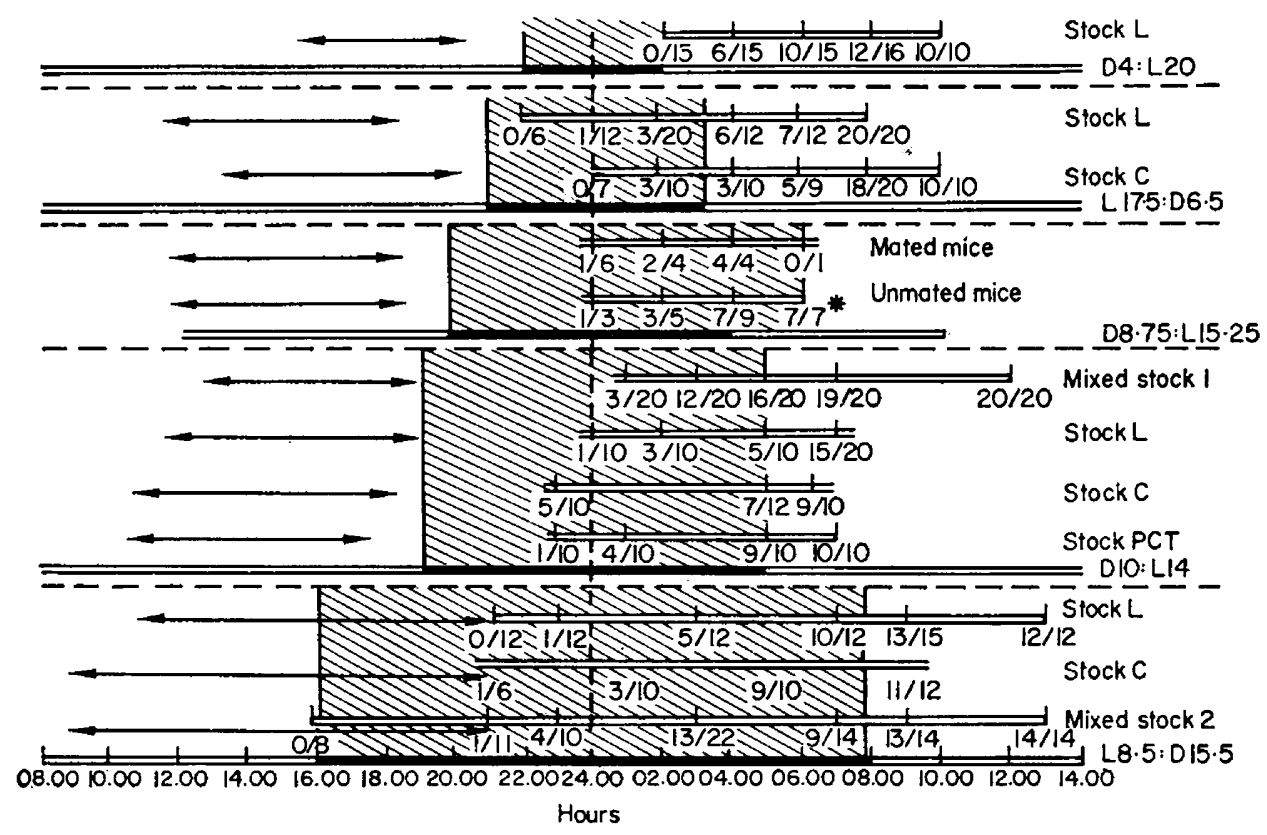

TexT-FIg. 1. Time of cyclic ovulation in mice under various lighting schedules. The data concerning stocks L, C, PCT, and mixed stock 2. (all groups mated) are modified from Braden (1957); mated and unmated mice (D8.75:L15.25), from Snell et al. (1940); mixed stock 1 (mated mice) from Braden \& Austin (1954). The black and hatched areas indicate the periods of darkness. $\mathrm{N} / \mathrm{N}=\mathrm{No}$. of mice ovulated/No. of mice at autopsy. Periods during which ovulation occurred in all the mice of a group are shown by the closed ends of the clear boxes. Arrows indicate the estimated beginning of LH release, assuming a 12-hr latent period. * One of the seven had been caged with a male but had not mated.

\section{MATERIALS AND METHODS}

The source, age and lighting conditions (lights on from 05.00 to 19.00 hours) of the mice have been described previously, as well as the techniques for obtaining vaginal smears and for determining the occurrence or non-occurrence of ovulation (Bingel \& Schwartz, 1969). Ovaries and oviducts were preserved for histological study for three purposes: (1) to determine in doubtful cases 
whether ovulation had or had not occurred as expected in an untreated or saline-injected animal; (2) to determine the completeness or incompleteness of ovulation blockade in the barbital-injected animals (the first ovary was removed at 10.00 to 11.00 hours on the morning of expected oestrus); and (3) to determine whether a delayed ovulation had occurred (in the second ovary) in animals that had not ovulated by 10.00 to 11.00 hours on the morning of expected oestrus.

\section{Time of cyclic ovulation}

Mice exhibiting 4-, 5-, or 6-day cycles were anaesthetized with ether and subjected to laparotomy between 00.30 and 01.30 hours on the morning of expected oestrus (Bingel \& Schwartz, 1969) and again between 05.00 and 06.00 hours; if ovulation had not occurred by the time of the second laparotomy, a third laparotomy was carried out at 08.30 and/or 10.00 to 10.30 hours.

TABLE 1

TIME OF OVULATION IN GYGLIC MIGE

\begin{tabular}{|c|c|c|c|c|c|c|}
\hline \multirow[b]{2}{*}{$\begin{array}{l}\text { Cycle } \\
\text { length }\end{array}$} & \multirow[b]{2}{*}{$\begin{array}{l}\text { No. } \\
\text { mice }\end{array}$} & \multirow[b]{2}{*}{$\begin{array}{c}\text { No. } \\
\text { ovulating }\end{array}$} & \multicolumn{4}{|c|}{ Time of day (hours) } \\
\hline & & & $\begin{array}{c}01.00 * \dagger \\
\text { to } \\
05.30 * \dagger\end{array}$ & $\begin{array}{c}05.00 \ddagger \\
\text { to } \\
05.30 \ddagger\end{array}$ & $\begin{array}{c}05.00 \dagger \\
\text { to } \\
10.30 \dagger\end{array}$ & $\begin{array}{c}08.30 \dagger \\
\text { to } \\
10.30 \dagger\end{array}$ \\
\hline $\begin{array}{l}\text { 4-Day } \\
\text { 5-Day } \\
\text { 6-Day }\end{array}$ & $\begin{array}{r}9 \\
13 \\
1\end{array}$ & $\begin{array}{r}6 \\
12 \\
1\end{array}$ & $\begin{array}{r}2 \\
9 \\
-\end{array}$ & $\begin{array}{c}2(05.00,05.30) \\
1(05.30) \\
1(05.30)\end{array}$ & $\underline{2}$ & $\overline{2}$ \\
\hline Totals & 23 & 19 & 11 & 4 & 2 & 2 \\
\hline
\end{tabular}

\section{Delineation of critical period for $\mathrm{LH}$ release}

The time at which the ovulatory release of LH normally occurs was inferred by determining the period during which this release could be prevented. Mice exhibiting regular 5-day oestrous cycles were injected with barbital, $400 \mathrm{mg} / \mathrm{kg}$ i.p. (preliminary investigations by the authors had indicated that a dose of 200 $\mathrm{mg} / \mathrm{kg}$ was ineffective), at one of the following times: 05.00, 09.00, 13.00, 14.00, $16.00,17.00$ or 21.00 hours of pro-oestrus, or at 01.00 hours of oestrus; similarly cyclic mice were injected with saline as controls. Laparotomy was carried out on all of the animals between 10.00 and 11.00 hours on the day of expected oestrus to determine whether or not ovulation had occurred. Animals which were 'blocked' were observed subsequently for delayed ovulation.

\section{RESULTS}

Time of cyclic ovulation

The data concerning the time of ovulation in cyclic mice are shown in Table 1; ovulation tended to occur during the late hours of the dark period or early 
hours of the light period. Ovulation was in the process of occurring in four mice at the onset of the light period; that is, both new corpora lutea and follicles that seemed on the point of rupturing were found in their ovaries (PI. 1, Fig. 1). Ovulation took place in four others after the light period began. The second ovary and oviduct of three of the four mice that had been in the process of

TABLE 2

BARBITAL AND SALINE EFFECTS ON OCGURRENCE OF OVULATION

\begin{tabular}{|c|c|c|c|}
\hline Type ${ }^{\text {Treatment }}$ Time & $\begin{array}{l}\text { No. ovulated } \\
\text { no. injected }\end{array}$ & $\begin{array}{c}\text { No. } S F^{*} / \\
\text { no. injected }\end{array}$ & $\begin{array}{l}\text { Total no. in which } \\
\text { LH action was observed }\end{array}$ \\
\hline $\begin{array}{r}\text { Saline } \\
13.00 \text { (Pro-oestrus) } \\
14.00 \text { (Pro-oestrus) } \\
16.00 \text { (Pro-oestrus) } \\
17.00 \text { (Pro-oestrus) } \\
\text { Subtotals }\end{array}$ & $\begin{array}{l}10 / 14 \\
3 / 5 \\
2 / 2 \\
2 / 2 \\
17 / 23\end{array}$ & $\begin{array}{l}0 / 13 \dagger \\
0 / 5 \\
0 / 2 \\
0 / 2 \\
0 / 22\end{array}$ & $\begin{array}{c}\text { 'Saline Controls' } \\
\text { (Pro-oestrus) } \\
17 / 22\end{array}$ \\
\hline $\begin{array}{r}\text { Barbital } \\
05.00 \text { (Pro-oestrus) } \\
09.00 \text { (Pro-oestrus) } \\
13.00 \text { (Pro-oestrus) }\end{array}$ & $\begin{array}{l}3 / 6 \\
1 / 5 \\
3 / 9\end{array}$ & $\begin{array}{l}0 / 6 \\
1 / 5 \\
0 / 8\end{array}$ & $\begin{array}{c}\text { 'Early barbital' } \\
\text { (Pro-oestrus) } \\
8 / 19\end{array}$ \\
\hline Subtotals & $7 / 20$ & $1 / 19$ & \\
\hline $\begin{array}{r}\text { Barbital } \\
14.00 \text { (Pro-oestrus) } \\
16.00 \text { (Pro-oestrus) } \\
17.00 \text { (Pro-oestrus) }\end{array}$ & $\begin{array}{l}0 / 4 \\
0 / 1 \\
0 / 4\end{array}$ & $\begin{array}{l}0 / 4 \\
0 / 1 \\
0 / 4\end{array}$ & $\begin{array}{c}\text { 'Afternoon barbital' } \\
\text { (Pro-oestrus) } \\
0 / 9\end{array}$ \\
\hline Subtotals & $0 / 9$ & $0 / 9$ & \\
\hline $\begin{array}{l}\text { Barbital } \\
21.00 \text { (Pro-oestrus) } \\
01.00 \text { (Oestrus) }\end{array}$ & $\begin{array}{l}0 / 5 \\
3 / 4\end{array}$ & $\begin{array}{l}4 / 5 \\
1 / 4\end{array}$ & $\begin{array}{c}\text { 'Late barbital' } \\
\text { (Pro-oestrus-Oestrus) }\end{array}$ \\
\hline Subtotals & $3 / 9$ & $5 / 9$ & \\
\hline
\end{tabular}

* $\mathrm{SF}=$ Stimulated follicles in ovary, but no new corpora lutea.

† Ovaries from one of these animals were not observed histologically.

$\ddagger$ Observations between 10.00 and 11.00 hours on day of expected oestrus.

ovulating when they were first observed, were removed at 08.30 or 10.30 hours; ovulation had been completed in all (Pl. 1. Fig. 2). Ovulation had not occurred by 10.30 hours of the day of predicted 'oestrus' in four of the twenty-

\section{EXPLANATION OF PLATE 1}

FIG. 1. Section from an ovary removed during ovulation, at 05.30 hours at oestrus. A very stimulated follicle that would probably soon have ruptured can be seen next to a newly formed, deep blue corpus luteum. H \& $\mathrm{E}, \times 80$.

FIg. 2. The second ovary of a mouse whose first ovary is shown in Fig. 1 was removed at 10.30 hours at oestrus. It contained new corpora lutea and no stimulated follicles. $\times 80$.

FIG. 3. The ovary containing this follicle was removed at 11.00 hours at 'oestrus.' The animal had been injected with barbital at 21.00 hours at pro-oestrus, approximately $8 \mathrm{hr}$ before the expected time of ovulation. This follicle is slightly stimulated; ovum still attached to wall of follicle, but cumulus cells surrounding it have begun to disperse. $\times 80$.

FIG. 4. The ovary containing this follicle was removed at 11.00 hours at 'oestrus.' The animal had been injected with barbital at 17.00 hours at pro-oestrus, approximately $12 \mathrm{hr}$ before the expected time of ovulation. This follicle is not stimulated; cumulus cells are still tightly packed around ovum. $\times 80$. 


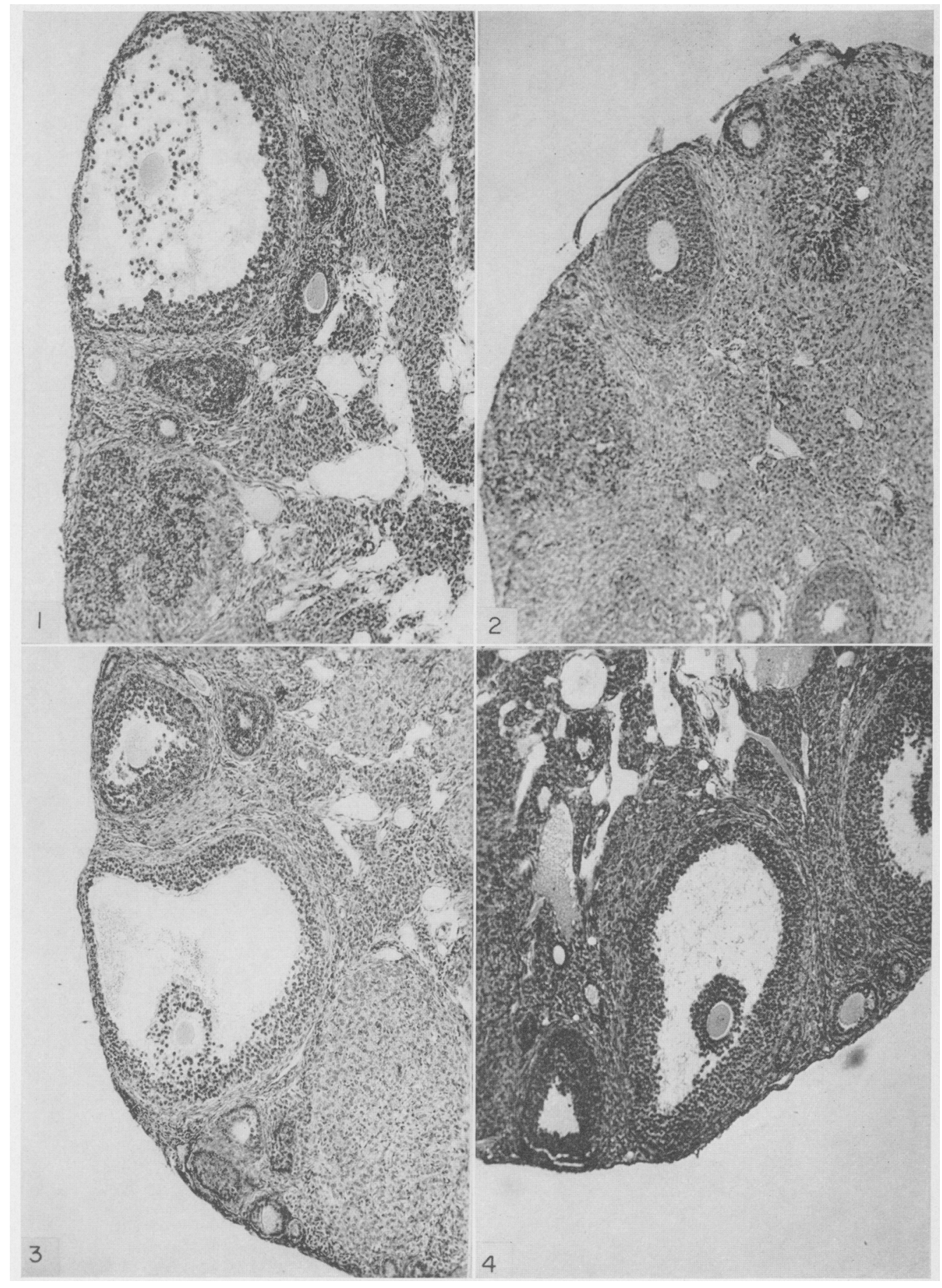

(Iracing $/ 1.226$ 
three mice examined. Three of the four were observed subsequently, at 'metoestrus,' and still had not ovulated.

\section{Determination of critical period for $L H$ release}

The data concerning the effects of barbital on the occurrence of cyclic ovulation are summarized in Table 2. The presence of stimulated follicles (P1. 1, Fig. 3) and/or newly formed corpora lutea were taken to indicate that at least some LH had been released and had acted on the ovary. Of twenty-three mice injected with saline, seventeen had ovulated, a proportion which compares favourably with the data in Table 1 . When barbital was given during the afternoon of pro-oestrus, none of nine animals ovulated and the follicles in their ovaries were not stimulated (Pl. 1, Fig. 4); in contrast, seven of nine mice injected with saline at comparable times $(14.00,16.00$ and 17.00 hours) on the afternoon of pro-oestrus did ovulate $(P=0.002$; Mainland, Herrera \& Sutcliffe, 1956).

The ability of barbital to block LH release depended significantly upon the time at which it was injected. Afternoon injections were effective; early and late injections were not $\left(\chi^{2}=14.51, P<0.001\right.$; Snedecor, 1956). The anaesthetic effect of the early injections was observed to be wearing off by late afternoon, apparently permitting some of the mice to release $\mathrm{LH}$; the late injections apparently were given after at least some of the LH had been released.

Nineteen of the twenty-one barbital-injected mice known to be completely blocked (no new corpora lutea and no stimulated follicles in their ovaries at 'oestrus') were observed subsequently for delayed ovulation. Of these, six had ovulated, or at least had begun to ovulate, by 11.00 hours on 'metoestrus'; two showed only stimulated follicles at that time. Four of the six saline controls that had not ovulated were observed subsequently; one had ovulated by 08.00 hours of 'metoestrus'.

\section{DISGUSSION}

The time of ovulation in unmated cyclic mice exposed to L14:D10 (lights on from 05.00 to 19.00 hours) was found to be variable, but the degree of variability did not differ greatly from that found previously in mated, and a small number of unmated, mice (Snell et al., 1940; Braden \& Austin, 1954; Braden, 1957; see Text-fig. 1). Ovulation in the present study as a whole took place within a 9-hr period (Table 1). Text-figure 1 reveals that ovulation for mated mice similarly tended to occupy 8- to 10 -hour periods for $\mathrm{L}: \mathrm{D}$ ratios ranging from $20 \mathrm{hr}$ of light and $4 \mathrm{hr}$ of darkness to $14 \mathrm{hr}$ of light and $10 \mathrm{hr}$ of darkness. However, when the length of the dark period exceeded the length of the light period (L8.5:D15.5), ovulation occurred over an even broader time interval of approximately 13 to $16 \mathrm{hr}$.

Results of the barbital treatment (Table 2) indicate a late-afternoon to earlyevening critical period for $\mathbf{L H}$ release in the unmated cyclic mouse under L14:D10; when barbital was administered at $14.00,16.00$ or 17.00 hours on the day of pro-oestrus, LH release and ovulation were blocked. On the other hand, the anaesthetic effect of early injections apparently subsided in some of the 
animals by the time of the critical period, permitting them to release LH and ovulate. Perhaps the most suggestive piece of evidence in support of a late critical period of $\mathrm{LH}$ release is the observation that no indication of $\mathrm{LH}$ release was found in the ovaries on the morning of 'oestrus' in the four mice given barbital at 17.00 hours; however, at least some LH is released by 21.00 hours since four of the five mice injected at this time did exhibit a slight degree of follicular stimulation (see Pl. 1, Fig. 3). Of further interest is the marked resemblance between the follicles in the ovaries of mice injected with barbital 12 and $8 \mathrm{hr}$ before the expected time of ovulation (Pl. 1, Figs. 3 and 4) and the follicles in the ovaries of untreated mice removed 12 and $8 \mathrm{hr}$, respectively, before occurrence of ovulation in the contralateral ovary (Bingel \& Schwartz, unpublished observations).

In the six mice observed which were exhibiting 4-day cycles, ovulation occurred during the same time period as it did in the mice with 5-day cycles, and a similarly late critical period of $\mathrm{LH}$ release might therefore be expected in the mice with the shorter cycle. The small number of such mice available prevented the testing of this hypothesis. Both the time of $\mathbf{L H}$ release and the time of ovulation in the mice with a longer cycle (and at least the time of ovulation in the mice with a shorter cycle) are later than that found in the rat with a shorter cycle; $L_{H}$ is released between 14.00 and 16.00 hours at pro-oestrus and the rat ovulates close to 02.00 hours at oestrus (Everett, 1961; Mills \& Schwartz, 1961; Schwartz \& Bartosik, 1962; Schwartz \& Caldarelli, 1965). An exact comparison of mice exhibiting 5-day cycles with rats exhibiting this cycle length, awaits further investigation in the rat.

\section{ACKNOWLEDGMENTS}

The authors wish to thank Mr William L. Talley for preparing the tissues for histological examination. This study was supported in part by PHS Grants HD-00440 and TO1GM00738.

This work was submitted by one of us (A.S.B.) in partial fulfilment of the requirements for the degree of Doctor of Philosophy in Physiology, University of Illinois.

\section{REFERENGES}

Bingel, A. S. \& Schwartz, N. B. (1969) Pituitary Lh content and reproductive tract changes during the mouse oestrous cycle. 7 . Reprod. Fert. 19, 215.

BRADEN, A. W. H. (1957) The relationship between the diurnal light cycle and the time of ovulation in mice. 7. exp. Biol. 34, 177.

Braden, A. W. H. \& Austin, C. R. (1954) Fertilization of the mouse egg and the effect of delayed coitus and of hot-shock treatment. Aust. F. biol. Sci. 7, 552.

Everett, J. W. (1961) The mammalian female reproductive cycle and its controlling mechanisms. In: Sex and Internal Secretions, 3rd edn, Vol. I. Ed. W. G. Young. Williams \& Wilkins, Baltimore.

Hoffmann, J. C. \& Schwartz, N. B. (1965) Timing of post-partum ovulation in the rat. Endocrinology, 76,620 .

Mainland, D., Herrera, L. \& Sutcliffe, M. I. (1956) Tables for use with binomial samples, p. 10. N.Y. University College of Medicine, New York.

Mills, J. M. \& Schwartz, N. B. (1961) Ovarian ascorbic acid as an endogenous and exogenous assay for cyclic proestrous LH release. Endocrinology, 69, 344. 
Rowlands, I. W. \& Williams, P. C. (1943) Production of ovulation in hypophysectomized rats. $\mathcal{F}$. Endocr. 3, 310.

Runner, M. N. \& Palm, J. (1953) Transplantation and survival of unfertilized ova of the mouse in relation to postovulatory age. F. exp. Zool. 124, 306.

Schwartz, N. B. \& Bartosik, D. (1962) Changes in pituitary LH content during the rat estrous cycle. Endocrinology, 71, 756.

Schwartz, N. B. \& Caldarelli, D. (1965) Plasma lh in cyclic female rats. Proc. Soc. exp. Biol. Med. $119,16$.

SNEDECOR, G. W. (1956) Statistical methods, 5th edn, p. 225. Iowa State University Press, Ames.

SNell, G. D., Fexete, E., Hummell, K. P. \& Law, L. W. (1940) The relation of mating, ovulation, and the estrous smear in the house mouse to time of day. Anat. Rec. 76, 39. 